Doktoral Ilmu Hukum, Fakultas Hukum, Universitas Lampung, Bandar Lampung, Lampung, Indonesia.

Volume1 Issue 1, January-June 2020: pp: 59-70. http://jurnal.fh.unila.ac.id/index.php/plr

P-ISSN: 2723-262X

E-ISSN: $2745-9306$

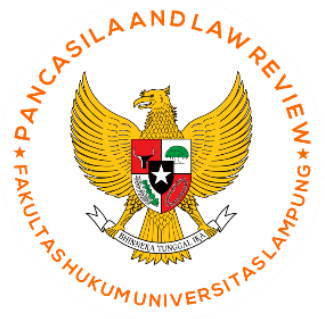

\title{
Nilai Pancasila Dalam Penanggulangan Bencana Alam Berdasarkan Undang-Undang Penanggulangan Bencana
}

\section{Pancasila Value in Natural Disaster Management Based on Disaster Management}

\author{
Erlinawati \\ erlinawati_76@yahoo.com \\ Yayasan Lembaga Miryam
}

Submitted: Apr 16, 2020; Reviewed: Apr 30, 2020; Accepted: Mei 18, 2020

Info Artikel
$\begin{aligned} & \text { Kata Kunci: Nilai-nilai Pancasila; } \\ & \text { bencana; penanggulangan bencana. }\end{aligned}$
Keywords: Pancasila values; disaster;
disaster management.

DOI:

https://doi.org/10.25041/plr.v1i1.2064
Abstrak

Penyelenggaraan penanggulangan bencana alam tidak bisa dilepaskan juga dari Pancasila dan Undang-Undang Dasar 1945 yang melandasinya. Nilai-nilai Pancasila digali dan temukan dari nilai-nilai yang telah tumbuh dan hidup dalam masyarakat, yakni nilai ketuhanan, kemanusiaan, persatuan, kerakyatan dan keadilan. Di dalam masyarakat nilai-nilai tersebut tetap berlaku dan merupakan satu kesatuan yang utuh, tak terpisahkan dan mengacu kepada tujuan yang satu. Penelitian ini bertujuan untuk mengetahui apakah nilainilai Pancasila termuat dalam Undang-Undang Nomor 24 Tahun 2007 tentang Penanggulangan Bencana, dan bagaimanakah implementasi nilai-nilai Pancasila dalam Penanggulangan Bencana alam. Metode penelitian yang digunakan adalah penilitian hukum normatif empiris dengan pendekatan perundang-undangan (statute approach), Tulisan ini bersifat deskriptif, dengan menggunakan data primer dan data sekunder bersifat kualitatif. Hasil analisis data dibahas 
dengan menggunakan pendekatan undangundang (statute approach) dan pendekatan konseptual (conceptual approach).

Hasil penelitian adalah Undang-undang nomor 24 Tahun 2007 telah memuat nilai-nilai Pancasila, yakni nilai ketuhanan, kemanusiaan, persatuan, kerakyatan dan keadilan. Nilai kemanusiaan, kerakyatan dan keadilan selain secara tegas disebutkan dalam beberapa pasal, juga tersirat dalam pasal-pasal. Nilai ketuhanan dan persatuan tersirat di dalam beberapa pasal. Implementasi nilai-nilai Pancasila dalam penganggulangan bencana alam di Kabupaten Lampung Selatan terwujud dalam kegiatan penyelenggaraan penanggulangan bencana, mulai dari pra bencana, saat tanggap darurat maupun pasca bencana.

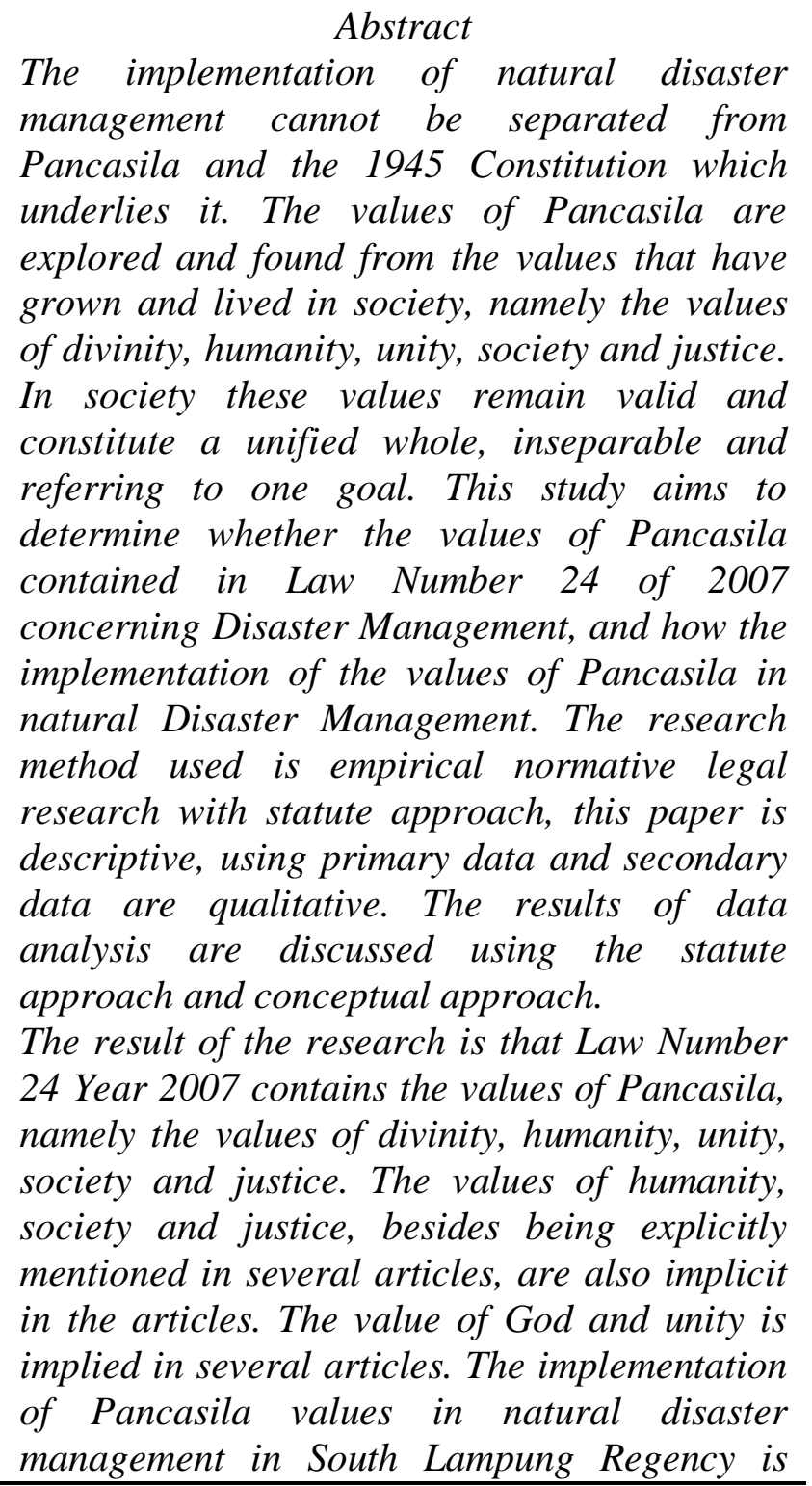


manifested in the activities of disaster

management, starting from pre-disaster, during

emergency response and post-disaster.

\section{A. Pendahuluan}

Indonesia berada di daerah rawan bencana. Salah satu daerah di Propinsi Lampung, tepatnya di Kabupaten Lampung Selatan berpotensi terjadi bencana, diantaranya adalah: tsunami, gunung berapi, banjir, tanah longsor, dan puting beliung. Bencana tsunami terakhir kali terjadi di Kabupaten Lampung selatan pada tanggal 22 Desember 2018 tepatnya di Selat Sunda. Wilayah terdampak bencana meliputi 4 Kecamatan, yaitu Kecamatan Kalianda, Rajabasa, Sidomulyo, dan Katibung. Masyarakat yang terdampak bencana sebagian besar berada di daerah zona merah dan seharusnya sudah direlokasi, tetapi dalam hal ini pemerintah daerah juga tidak mampu merelokasi semua.

Terjadinya bencana alam dalam suatu daerah membutuhkan penanganan yang serius. Pemerintah memiliki peran penting dalam penyelenggaran penanggulangan bencana, akan tetapi seluruh elemen masyarakat pun memiliki tanggung jawab yang besar pula. Keterlibatan setiap elemen masyarakat tersebut sejatinya berdasarkan atas prinsip kemanusiaan. Dengan demikian ketika terjadi bencana alam, sesorang tidak perlu mempertanyakan latar belakang sesama yang akan ditolongnya, baik itu suku, agama, ataupun ras.

Pancasila dan Undang-Undang Dasar 1945 menjadi landasan utama dalam penyelenggaraan penanggulangan bencana. Sebelum Indonesia merdeka nilai-nilai Pancasila digali dan temukan dari nilai-nilai yang telah tumbuh dan hidup dalam masyarakat. Nilai-nilai tersebut adalah nilai ketuhanan, kemanusiaan, persatuan, kerakyatan dan keadilan. Di dalam masyarakat nilai-nilai tersebut tetap berlaku dan merupakan satu kesatuan yang utuh, tak terpisahkan dan mengacu kepada tujuan yang sama. Nilai-nilai Pancasila memiliki arti penting dalam penanggulangan bencana, baik itu pada tahap pra bencana, saat tanggap darurat maupun pasca bencana. Demikian pula dalam memperkuat ketangguhan masyarakat ketika menghadapi bencana alam.

Dalam penelitian ini hendak mengkaji permasalahan: 1) Apakah Undang-Undang Penanganan Bencana telah memuat nilai-nilai Pancasila? 2) Bagaimanakah nilai-nilai Pancasila diimplementasikan dalam Penanggulangan Bencana alam? Metode penelitian yang digunakan adalah penilitian hukum normatif empiris dengan pendekatan perundang-undangan (statute approach), Tulisan ini bersifat deskriptif, dengan menggunakan data primer dan data sekunder bersifat kualitatif. Data disusun secara sistematis dan dianalisis secara kualitatif. Hasil analisis data dibahas menggunakan pendekatan undang-undang (statute approach) dan pendekatan konseptual (conceptual approach).

\section{B. Pembahasan}

\section{Pemahaman tentang Bencana}

Carter membagi bencana menjadi dua, yaitu 'ancaman tradisional' (The Traditional Disaster Threat) dan 'ancaman baru' (The New Disaster Threats) ${ }^{1}$ Berdasarkan penyebabnya menurut Amhar dan Darmawan, secara umum terdapat tiga jenis bencana, yakni bencana geologis, bencana meteorologis dan bencana anthropogenis (disebabkan manusia) ${ }^{2}$. Dari berbagai jenis bencana, terdapat enam bencana yang paling mengancam daerah-daerah di

\footnotetext{
${ }^{1}$ Carter. Nick, Disaster management: A Disaster Manager's Handbook, ADB, Manila, 1991, hlm. 3

2 Amhar, Fahmi dan Darmawan, Mulyanto, A Study on Multihazard Maps, Panduan Pengenalan Karakteristik Bencana dan Upaya Mitigasinya di Indonesia, Badan Koordinasi Nasional Penanggulangan Bencana dan Penanganan Pengungsi, Jakarta, 2007.
} 
Indonesia, yakni tsunami, gempa bumi, banjir dan banjir bandang, kebakaran gedung, tanah longsor, serta letusan gunung api. ${ }^{3}$

Definisikan bencana menurut Asian Disaster Preparedness Center (ADPC) dirumuskan sebagai berikut:

"The serious disruption of the functioning of society, causing widespread human, material or environmental losses, which exceed the ability of the affected communities to cope using their own resources. Disasters occur when the negative effects of the hazards are not well managed.".

Berdasarkan Undang-Undang Penanggulangan Bencana, bencana diartikan sebagai peristiwa atau rangkaian peristiwa yang mengancam dan mengganggu kehidupan dan penghidupan masyarakat. Penyebabnya adalah faktor alam dan/atau faktor nonalam serta faktor manusia. Akibatnya timbul korban jiwa manusia, kerusakan lingkungan, kerugian harta benda, dan dampak psikologis. ${ }^{5}$

Menghadapi bencana alam, sebagian besar masyarakat masih kurang siap dalam mengantisipasinya. Oleh karena itu perlu manajemen bencana agar dapat mengurangi kerugian fisik, ekonomi maupun jiwa, baik perorangan, masyarakat mempercepat pemulihan, dan memberikan perlindungan kepada pengungsi atau masyarakat yang kehilangan tempat ketika kehidupannya terancam ${ }^{6}$ Undang-undang penanggulangan bencana menegaskan bahwa penyelenggaraan penanggulangan bencana mencakup kegiatan pencegahan bencana, tanggap darurat, dan rehabilitasi serta penetapan kebijakan pembangunan yang berisiko timbulnya bencana. Paradigma baru yang harus menjadi bagian penting dalam pengelolaan penanggulangan bencana adalah kesiapsiagaan masyarakat untuk pengurangan risiko bencana. Masyarakat yang berada di daerah rawan bencana harus memiliki kesiapsiagaan yang tinggi, dengan cara meningkatkan pengetahuan dan keterampilan. ${ }^{7}$ Penanggulangan bencana berbasis masyarakat dapat diwujudkan ketika masyarakat menggunakan sumber daya sendiri untuk mengurangi resiko dengan mencegah, mengurangi, menghindari, dan memulihkan dampakdampak yang diakibatkan oleh adanya bencana. ${ }^{8}$

\section{a. Nilai-Nilai Pancasila dalam Undang-Undang Nomor 24 Tahun 2007 tentang Penanggulangan Bencana}

Nilai-nilai Pancasila berasal dari budaya dan masyarakat Indonesia, dan bukan ideologi yang diimpor atau ideologi asing. Nilai yang terkandung di dalamnya merupakan nilai dasar yang perlu diuraikan ke dalam nilai intrumental. ${ }^{9}$ Notonagoro berpendapat bahwa nilai-nilai Pancasila tergolong nilai-nilai kerohanian, yang mengakui adanya nilai material dan nilai vital. Di dalam nilai kerohanian itu, terkandung juga nilai-nilai lain secara lengkap dan harmonis, yang meliputi nilai material, kebaikan atau moral, kebenaran, vital, keindahan atau estetis, maupun kesucian yang sistematis hierarkhis, dimulai dari sila Ketuhanan Yang Maha Esa sebagai 'dasar' sampai dengan sila Keadilan sosial bagi seluruh rakyat Indonesia sebagai 'tujuan'. ${ }^{10}$

\footnotetext{
${ }^{3}$ Eny Supartini, dkk, Buku Pedoman Latihan Kesiapsiagaan Bencana, BNPB, 2017, hlm. 28

${ }^{4}$ Imelda Abarquez and Zubair Murshed, field practitioners' handbook, 2004, Thailand, page.6

${ }^{5}$ Pasal 1 angka 1 UU Nomor 24 Tahun 2007

${ }^{6}$ Hadi Purnomo dan Ronny Sugiantoro, Manajemen Bencana, Media Pressindo, Yogyakarta, 2010, hlm. 93

7 Deny Hidayat, Kesiapsiagaan Masyarakat: Paradigma Baru Pengelolaan Bencana Alam Di Indonesia, Jurnal Kependudukan Indonesia, Vol. III, No. I, 2008, hlm. 82

${ }^{8}$ Alexius Sunaryo, Mitigasi Bencana Sosial Politik Sebagai Kebijakan Publik Berbasis Demokrasi Pancasila, Mimbar Administrasi Fakultas Ilmu Sosial Dan Ilmu Politik Universitas 17 Agustus 1945 Semarang, Vol. 15 No. 29 Edisi Oktober 2019, ISSN 0854-3542, hlm. 152

${ }^{9}$ Winarno, Paradigma Baru Pendidikan Pancasila, Penerbit Bumi Aksara, Jakarta, 2016, hlm. 102

${ }^{10}$ Kaelan, M.S., Filsafat Pancasila, Penerbit "Paradigma”, Yogyakarta, 2009, hlm. 127
} 
Dalam pembangunan sistem hukum nasional, cita hukum Pancasila memiliki tiga nilai yaitu nilai dasar, nilai instrumental, dan nilai praktis, diaktualisasikan ke dalam norma-norma hukum. Nilai-nilai Pancasila sebagai bintang pemandu untuk menguji dan memberikan arah pada hukum positif Indonesia. ${ }^{11}$ Pancasila sebagai nilai terdiri dari lima nilai, yang merupakan satu kesatuan yang utuh, tak terpisahkan, yakni nilai ketuhanan, kemanusiaan, persatuan, kerakyatan, keadilan. Nilai-nilai tersebut merupakan cita-cita, harapan, dambaan bangsa Indonesia yang akan diwujudkan dalam kehidupan. ${ }^{12}$

Nilai-nilai Pancasila dalam Undang-undang Nomor 24 Tahun 2007:

1) Nilai Ketuhanan

Penghayatan terhadap nilai ketuhanan hendak menegaskan keyakinan mendasar, bahwa Tuhan adalah sesuatu yang hakiki diakui keberadaan-Nya oleh seluruh manusia Indonesia. Nilai atau prinsip ketuhanan dapat dijadikan sebagai pengikat keseluruhan manusia dan masyarakat Indonesia. Terjadinya bencana alam tidak dapat diartikan sebagai hukuman Tuhan atas perilaku manusia yang jahat. ${ }^{13}$ Nilai ketuhanan dalam Undang-undang tersebut tersirat dalam Pasal 3 ayat (2) huruf i, yakni prinsip nonproletisi dalam penanggulangan bencana. Berdasarkan prinsip nonproletisi, penanggulangan bencana dilarang menyebarkan agama atau keyakinan pada saat keadaan darurat bencana, terutama melalui pemberian bantuan dan pelayanan darurat bencana.

2) Nilai Kemanusiaan

Soekarno merumuskan rasa perikemanusiaan sebagai hasil dari pertumbuhan rohani, kebudayaan, dari alam tingkat rendah ke taraf yang lebih tinggi. Perikemanusiaan adalah hasil dari evolusi di dalam kalbunya manusia. ${ }^{14}$ Setiap orang harus menghormati dan menghargai orang lain sebagai sesama manusia, oleh karena itu dituntut sikap adil dalam memperlakukan sesamanya tanpa melihat suku, ras, ataupun perbedaan lainnya. ${ }^{15}$ Nilai kemanusiaan dengan tegas diatur dalam Pasal 3 ayat (1) huruf a bahwa penanggulangan bencana berasaskan kemanusiaan. Nilai kemanusiaan terdapat pula dalam prinsip-prinsip penanggulangan bencana, yakni prinsip cepat dan tepat (Pasal 3 ayat (2) huruf a), prinsip prioritas (Pasal 3 ayat (2) huruf b). Kegiatan penanggulangan bencana pertama-tama yang harus mendapat prioritas dan diutamakan adalah pada kegiatan penyelamatan jiwa manusia. Dalam Pasal 48 huruf c, d, dan e Prioritas tindakan kemanusiaan adalah penyelamatan dan evakuasi, pemenuhan kebutuhan dasar dan perlindungan terhadap kelompok rentan. Ketentuan tersebut lebih lanjut dijabarkan dalam Pasal 52 dan Pasal 53. Prioritas tindakan pada kelompok rentan sebagaimana dimaksud dalam Pasal 48 huruf e lebih lanjut diatur dalam Pasal 55 ayat (2) terdiri atas bayi, balita, dan anak-anak; ibu yang sedang mengandung atau menyusui; penyandang cacat; dan orang lanjut usia.

Nilai kemanusiaan terkandung pula dalam Pasal 4 huruf a, yakni di dalam tujuan penanggulangan bencana, antara lain memberikan perlindungan kepada masyarakat dari ancaman bencana, yang terdapat juga dalam Pasal 6 huruf $b$ dan Pasal 8 huruf a, b. Pemenuhan kebutuhan dasar untuk mendapatkan perlindungan sosial dan rasa aman merupakan salah satu perwujudan nilai kemanusiaan yang dilakukan Pemerintah. Demikian pula hak setiap orang untuk mendapatkan pendidikan, pelatihan dan keterampilan, mendapatkan informasi tentang kebijakan penyelenggaraan penanggulangan bencana ${ }^{16}$.

\footnotetext{
${ }^{11}$ Fais Yonas Bo'a, Pancasila Dalam Sistem Hukum, Pustaka Pelajar, Yogyakarta, 2017, hlm. 117

${ }^{12}$ Kaelan, M.S,op.cit, hlm.128

${ }^{13}$ Pusat Studi Pancasila Universitas Katolik Parahyangan, Pancasila Kekuatan Pembebas, Penerbit PT Kanisius, Yogyakarta, 2012, hlm. 74

${ }^{14}$ Ir. Soekarno, Filsafat Pancasila menurut Bung Karno, Media Pressindo, Yogyakarta, 2016, hlm. 205

15 Eko A Meinarno Sri Fatmawati Mashoedi, Pembuktian Kekuatan Hubungan Antara Nilai-Nilai Pancasila Dengan Kewarganegaraan, Jurnal Ilmiah Pendidikan Pancasila dan Kewarganegaraan, Th. 1, Nomor 1, Juni 2016, hlm. 14

${ }^{16}$ Pasal 26 ayat (1) huruf a, b, c dan ayat (2) Undang Undang Nomor 24 Tahun 2007
} 
Nilai kemanusiaan berkaitan erat dengan kelestarian lingkungan hidup. Setiap orang berkewajiban menjaga dan merawat kelestarian lingkungan. Penyelenggaraan penanggulangan bencana berdasarkan Pasal 31 huruf $b$ harus memperhatikan aspek kelestarian lingkungan hidup.

1. Nilai Persatuan

Kesatuan wilayah merupakan salah satu aspek nilai persatuan. Berdasarkan Pasal 31 huruf d penyelenggaraan penanggulangan bencana dilaksanakan berdasarkan aspek lingkup luas wilayah. Terjadinya bencana di satu daerah merupakan keprihatian bersama, oleh karena itu dalam menentukan kebijakan harus memperhatikan materi yang ada dalam ketentuan penanggulangan bencana harus mengarah pada kelestarian lingkungan demi kepentingan bangsa dan negara.

2. Nilai Kerakyatan

Nilai kerakyatan pada Pasal 74 ayat (1) berkaitan dengan penyelesaian sengketa pada tahap pertama diupayakan dengan asas musyawarah mufakat. Nilai kerakyatan juga menekankan makna saling membantu (bergotong royong), tanggung jawab sosial, dan solidaritas. Sejak Indonesia belum menjadi negara, gotong royong sudah menjadi bagian dari kebudayaan yang diwariskan. ${ }^{17}$ Dalam pandangan hidup orang Lampung, Sakai Sambaian (gotong royong) adalah salah satu unsur yang dinilai sebagai sesuatu yang baik, yang perlu dihadirkan dalam relasi sosial. ${ }^{18}$

Penanggulangan bencana pada dasarnya menjadi tugas dan tanggung jawab bersama Pemerintah dan masyarakat yang dilakukan secara gotong royong. Bergotong royong dapat dimaknai sebagai suatu tindakan yang dilakukan dalam semangat kebersamaan. Salah satu asas penanggulangan bencana Pasal 3 ayat (1) huruf f yakni asas kebersamaan.

Prinsip koordinasi, keterpaduan dan kemitraan dalam Pasal 3 ayat (2) huruf $c$, $f$ dan $g$ adalah bahwa penanggulangan bencana didasarkan pada koordinasi yang baik dan saling mendukung, dilakukan oleh berbagai sektor secara terpadu yang didasarkan pada kerja sama yang baik dan saling mendukung dalam semangat pemberdayaan. Nilai kerakyatan terwujud dalam partisipasi dan kemitraan publik serta swasta, semangat gotong royong, kesetiakawanan dan kedermawanan sebagaimana terdapat pada Pasal 4 huruf d, e. Sesuai dengan Pasal 26 ayat (1) huruf d, e, f masyarakat memiliki hak untuk berperan serta dalam perencanaan, pengoperasian dan pemeliharaan program penyediaan bantuan pelayanan kesehatan. Masyarakat juga berhak untuk berpartisipasi dalam pengambilan keputusan terhadap kegiatan penanggulangan bencana, khususnya yang berkaitan dengan diri dan komunitasnya, serta melakukana pengawasan sesuai mekanisme yang berlaku. Peran serta masyarakat, lembaga usaha dan lembaga internasional ditaur dalam Pasal 27, 28 dan 29.

Pada Pasal 14 diatur tentang perumusan konsep kebijakan penanggulangan bencana nasional, pemantauan dan evaluasi penyelenggaraan penanggulangan bencana oleh unsur pengarah penanggulangan bencana melibatkan pejabat pemerintah terkait dan anggota msyarakat profesional yang dipilih melalui uji kepatutan oleh Dewan Perwakilan Rakyat (DPR). Masyarakat dapat berpartisipasi aktif melibatkan diri dalam urusan-urusan publik. Berkaitan dengan pendanaan berdasarkan Pasal 60 ayat (2) peran Pemerintah dan Pemerintah Daerah adalah mendorong partisipasi masyarakat agar dapat berperan serta dalam penyelenggaraan penanggulangan bencana. Peran serta masyarakat sebagai bentuk kemandirian dan tanggung jawab sebagai individu.

3. Nilai Keadilan

Nilai keadilan termuat dalam UU No. 24 Tahun 2007 khususnya pada Pasal 3 ayat (1) huruf b: penanggulangan bencana berasaskan keadilan. Pasal 6 hurf c berkaitan dengan

\footnotetext{
${ }^{17}$ Agustinus W. Dewantara, Diskursus Filsafat Pancasila Dewasa ini, Penerbit PT Kanisius, Yogyakarta, 2017, hlm. 104

${ }^{18}$ Ani Rosiyati, Sakai Sambaian: Sistem Gotong Royong di Lampung Timur, Jurnal Patanjala volume 4 No. 1, Maret 2012, hlm. 100
} 
penjaminan pemenuhan hak masyarakat dan pengungsi yang terkena bencana. Pasal 21 huruf a berkaitan dengan tugas BPBD dalam menetapkan pedoman dan pengarahan terhadap usaha penanggulangan bencana secara adil dan setara.

Pada Pasal 3 ayat (2) huruf d,e, h juga tersirat adanya nilai keadilan, yakni berkaitan dengan prinsip berdaya guna dan berhasil guna dalam mengatasi kesulitan masyarakat. Dengan prinsip transparansi dan akuntabilitas penyelenggaraan penanggulangan bencana harus dilakukan secara terbuka dan dapat dipertanggungjawabkan. Prinsip nondiskriminasi jelas menunjukkan adanya nilai keadilan. Nilai keadilan juga tersirat dalam Pasal 32 ayat (2), bahwa setiap orang berhak atas ganti rugi sesuai apabila hak kepemilikannya dicabut atau dikurangi.

\section{Implementasi Nilai-Nilai Pancasila dalam Penanggulanan Bencana di Lampung Selatan}

Penanggulangan bencana merupakan tanggung jawab bersama seluruh elemen bangsa, oleh karena itu perubahan pada aspek kebijakan, kelembagaan, koordinasi, dan mekanisme memungkinkan terbukanya ruang untuk partisipasi masyarakat, lembaga swadaya masyarakat, dunia usaha, dan masyarakat internasional. ${ }^{19}$

Penyelenggaraan penanggulangan bencana meliputi tahap prabencana, saat tanggap darurat dan pascabencana. Tahap-tahap yang dilakukan mengacu pada Undang Undang Nomor 24 Tahun 2007 yang dilaksanakan dengan Peraturan Bupati Lampung Selatan Nomor 05 Tahun 2011 tentang Penanggulangan Bencana dan Peraturan Bupati Lampung Selatan Nomor 16 Tahun 2011 tentang Prosedur Tetap Penyelenggaraan Penanggulangan Bencana Daerah Kabupaten Lampung Selatan.

1) Prabencana

Perwujudan nilai kemanusiaan yang dilakukan Pemerintah Daerah berkaitan dengan hak setiap orang untuk mendapatkan pendidikan, pelatihan dan keterampilan dilakukan melalui upaya meningkatkan kesiapsiagaan aparat desa dan masyarakat terhadap bencana. Pemerintah Daerah melalui BPBD membuat desa siaga bencana, yang bertujuan agar masyarakat mengetahui hal-hal yang harus diperbuat baik saat tidak terjadi bencana maupun ketika terjadi bencana. Pelatihan yang diadakan dnengan sasaran utamanya adalah desa-desa pinggir pantai agar menjadi desa tangguh bencana. Kegiatan tersebut masih terbatas. Baru 5 desa yang dilatih yakni desa Banding, Sukaraja, Waymuli, Sidomulya dan Talangbaru. Dalam satu desa dipilih 60 orang yang dilatih, sehingga kalau terjadi bencana mereka tahu apa yang harus dikerjakan, dan bisa membantu warga yang lain.

\section{2) Tanggap Darurat}

Penetapan status tanggap darurat oleh Pemerintah Daerah Kabupaten Lampung Selatan tertuang dalam Keputusan Bupati Lampung Selatan Nomor: B/ 400/VI.02/HK/2018 tentang Penetapan Status Tanggap Darurat Penanganan Bencana Tsunami di Kabupaten Lampung Selatan. Penetapan status tanggap darurat ini dilakukan mengingat bencana tsunami yang melanda beberapa kawasan di wilayah Kabupaten Lampung Selatan pada tanggal 22 Desember 2018 telah menyebabkan korban jiwa dan terganggunya lingkungan dan pemukiman warga. Selain itu penetapan status tanggap darurat dilakukan untuk mengantisipasi meluasnya dampak bencana, menghilangkan atau meminimalisir dampak bencana.

Penetapan status tanggap darurat berlangsung selama 7 (tujuh) hari, terhitung sejak 23 Desember 2018 sampai dengan 29 Desember 2018 dan diperpanjangan terhitung mulai 30 Desember 2018 sampai dengan tanggal 05 Januari 2019. Meski telah mendapat tambahan waktu masa tanggap darurat, namun Pemerintah Daerah masih memandang perlu untuk

\footnotetext{
${ }^{19}$ Shanti Dwi Kartika, Politik Hukum Penganggulangan Bencana, Kajian Vol. 20 No. 4 Desember 2015, hlm. 338
} 
melakukan perpanjangan kedua masa tanggap darurat, terhitung mulai 06 Januari sampai dengan 19 Januari 2019.

Implementasi nilai kemanusiaan berkaitan prinsip-prinsip penanggulangan bencana dilakukan dengan cepat dan tepat. Respon cepat dan tepat pada saat terjadi bencana dilakukan oleh Pemerintah Daerah melalui BPBD dengan mendirikan posko pengendali yang memiliki tugas pokok mengarahkan, dan dalam koordinasi dengan pihak lain, seperti Dinas Sosial, Kesehatan, Polisi, TNI, Organisasi Masyarakat (Ormas), Lembaga Swadaya Masyarakat (LSM) terlibat aktif dengan berbagai upaya untuk evakuasi, pertolongan, pemenuhan kebutuhan dasar dan pencarian orang.

Nilai kemanusiaan juga terwujud dengan memberikan prioritas dan mengutamakan kegiatan penyelamatan jiwa manusia. Prioritas tindakan kemanusiaan berupa penyelamatan dan evakuasi, pemenuhan kebutuhan dasar dan perlindungan terhadap kelompok rentan. Penyelamatan dan evakuasi masyarakat yang terkena bencana.

Nilai kerakyatan terdapat dalam prinsip koordinasi, keterpaduan dan kemitraan (Pasal 3 ayat (2) huruf c, f dan g). Pemerintah Pusat melalui BNPB dan Kementrian Sosial serta Dinas Pendidikan bekerjasama dalam penyelenggaraan penanggulangan bencana. Keterlibatan berbagai pihak, partisipasi dan kemitraan publik serta swasta dalam semangat gotong royong, kesetiakawanan dan kedermawanan. Implikasi nilai kerakyatan dalam penanggulangan bencana juga terdalam bentuk berperan serta masyarakat dalam penyelenggaraan penanggulangan bencana sebagai bentuk kemandirian dan tanggung jawab sebagai individu. Masyarakat secara sosial memiliki kebudayaannya masing-masing. Nilai-nilai yang lahir dan berkembang di dalam suatu masyarakat berasal dari dirinya sendiri. ${ }^{20}$ Kearifan lokal yang diyakini memiliki nilai kebaikan dan menjadi acuan dalam bertindak pada kehidupan masyarakat, sehingga prinsip tersebut menjadi pola pikir dan tradisi pada kehiduan masyarakat setempat. ${ }^{21}$ Sikap dan tidakan saling membantu, bergotong-royong meringankan beban sesamanya, baik yang dilakukan dalam kerjasama antarwarga masyarakat, Pemerintah dan Pemerintah Daerah, maupun pihak-pihak lain, menunjukkan bahwa nilai kerakyatan yang menekankan makna saling membantu (bergotong royong), tanggung jawab sosial, dan solidaritas telah terwujud dalam pelaksanaan penanggulangan bencana. Kegiatan gotong royong kerja bakti biasanya dilakukan untuk mengerjakan sesuatu hal yang sifatnya untuk kepentingan umum. ${ }^{22}$ Semangat gotong royong yang telah tumbuh dan berkembang di dalam masyarakat menjadi modal sosial yang kuat dalam pembangunan masyarakat yang tangguh bencana. Modal sosial bermanfaat dalam upaya mengatasi masalah dalam masyarakat secara bersama dan merupakan sumber motivasi untuk mencapai peningkatan ekonomi suatu masyarakat atau bangsa, ${ }^{23}$ sehingga terciptanya masyarakat yang semakin mandiri. ${ }^{24}$

\section{Masa Transisi Darurat Menuju Pemulihan Pascabencana}

Status Transisi Darurat ke Pemulihan adalah keadaan ketika ancaman bencana cenderung menurun dan atau telah berakhir eskalasinya, akan tetapi gangguan kehidupan dan penghidupan masyarakat masih tetap berlangsung. ${ }^{25}$ Masa transisi tersebut dalam berbagai

\footnotetext{
${ }^{20}$ HS Tisnanta, Oki Hajiansyah Wahab, Dharma Setyawan, Modal Sosial Dan Komunitas Agama Sebagai Pendukung Instrumen Hukum Dalam Pengelolaan Sampah Di Kota Metro, Jurnal Pemikiran Islam, Volume 19, No. 2, 22 Oktober 2014, hlm. 269

${ }^{21}$ Idrus Ruslan, Dimensi Kearifan Lokal Masyarakat Lampung Sebagai Media Resolusi Konflik, Jurnal Kalam, Volume 12, No. 1, Juni 2018, hlm. 109

${ }^{22}$ Maulana Irfan, Metamorfosis Gotong Royong Dalam Pandangan Konstruksi Sosial, Prosiding Ks: Riset \& Pkm Volume: 4 Nomor: 1 Hal: 1 - 140 Issn: 2442-4480, 2016

${ }^{23}$ R.A. Tachya Muhamad, Bintarsih Sekarningrum, Yusar, Modal Sosial Dalam Penanggulangan Bencana Banjir (Kasus di Kabupaten Bandung, Jawa Barat), Jurnal Pemikiran dan Penelitian Sosiologi, Departemen of Sociology, Faculty of Social and Political Science, Universitas Padjadjaran, Bandung, 2017

${ }^{24}$ Rusydi Syahra, Modal Sosial: Konsep dan Aplikasi , Jurnal Masyarakat dan Budaya, Volume 5 No. 1 Tahun 2003, hlm. 20

${ }^{25}$ Pasal langka 5 Peraturan Kepala BNPB Nomor 03 Tahun 2016 Tentang Sistem Komando Penanganan Darurat Bencana
} 
peraturan tidak disebutkan jangka waktu maksimal dan hal-hal yang dilakukan selama masa transisi darurat menuju pemulihan dalam penanggulangan bencana. Berdasarkan Keputusan Bupati Lampung Selatan Nomor: B/125/VI.02/HK/2019 tentang Penetapan Status Masa Transisi Darurat Menuju Pemulihan Pasca Bencana Tsunami di Kabupaten Lampung Selatan, menunjukkan bahwa berakhirnya masa tanggap darurat penanggulangan bencana, tidak serta merta ditetapkan masa pascabencana. Sampai dengan akhir tahun 2019 belum ada penetapan status pascabencana yang berimplikasi pada tindakan-tindakan yang semestinya dilakukan pada masa pascabencana. Masa Transisi Darurat Menuju Pemulihan Pasca Bencana Tsunami di Kabupaten Lampung Selatan dalam jangka waktu 90 (sembila puluh) hari sejak tanggal 20 Januari 2019 sampai dengan 20 April 2019. Masa transisi diperpanjangan untuk waktu 30 (tiga puluh) hari, terhitung sejak tanggal 21 April 2019 sampai dengan 20 Mei 2019. Setelah perpanjangan masa transisi darurat menuju pemulihan pasca bencana tsunami berakhir, maka pada 21 Mei 2019 ditetapkan Perpanjangan Kedua Status Masa Transisi Darurat Menuju Pemulihan Pasca Bencana Tsunami di Kabupaten Lampung Selatan yang berlaku selama 60 (enam puluh) hari, sejak tanggal 21 Mei 2019 sampai dengan tanggal 19 Juli 2019.

Berdasarkan beberapa Surat Keputusan Bupati Lampung Selatan tersebut di atas, masa tanggap darurat berlangsung selama 28 (dua puluh delapan) hari terhitung sejak tanggal 23 Desember 2018 sampai dengan 19 Januari 2019. Sedangkan masa transisi darurat menuju pemulihan pasca bencana tsunami berlangsung selama 180 (seratus delapan puluh) hari, terhitung sejak 20 Januari 2019 sampai dengan 19 Juli 2019. Pada masa transisi Pemerintah Kabupaten Lampung Selatan menyiapkan lahan-lahan yang dapat dipergunakan untuk hunian sementara (Huntara). Penyediaan huntara di 9 titik yaitu di Desa Kunjir, Way Muli timur, Waymuli Induk, Sukaraja, Rajabasa, Banding, eks hotel 56, Sidomulya, KatibungTarahan dengan total huntara 357 unit. ${ }^{26}$ Pascabencana

Pascabencana merupakan masa pemulihan. Pemerintah Daerah dalam proses ke arah pemulihan melakukan pembuatan hunian tetap (huntap). Huntap tersebut di peruntukkan bagi korban bencana yang rumahnya termasuk dalam kriteria kerusakan berat, untuk rumah dengan kriteria rusak sedang renovasi dibantu oleh Pemerintah Propinsi, sedangkan untuk rumah dengan kriteria rusak ringan dibantu oleh Kabupaten. Kriteria kerusakan berat, sedang dan ringan ditetapkan dengan Surat Keputusan Bupati. Dalam hal ini implementasi nilai keadilan dalam penanggulangan bencana sangat aktual. Keadilan secara proporsional harus bdiberikan bagi setiap warga tanpa terkecuali.

\section{Kesimpulan}

Berdasarkan hasil penelitian dan analisa data dapat disimpulkan bahwa:

1. Undang-undang nomor 24 Tahun 2007 telah memuat nilai-nilai Pancasila, yakni nilai ketuhanan, kemanusiaan, persatuan, kerakyatan dan keadilan. Nilai kemanusiaan, kerakyatan dan keadilan selain secara tegas disebutkan dalam beberapa pasal, juga tersirat dalam pasal-pasal. Sedangkan nilai ketuhanan dan persatuan tersirat di dalam beberapa pasal.

2. Implementasi nilai-nilai Pancasila dalam penganggulangan bencana alam di Kabupaten Lampung Selatan terwujud dalam kegiatan penyelenggaraan penanggulangan bencana, mulai dari pra bencana, saat tanggap darurat maupun pasca bencana.

3. Penyelenggaraan penanggulangan bencana mulai dari pra bencana, saat tanggap darurat dan pascabencana telah diatur dalam Undang Undang Nomor 24 Tahun 2007, akan tetapi pada masa transisi menuju pemulihan belum ada peraturan yang secara jelas mengaturnya. Oleh karena itu perlu adanya regulasi yang mengatur secara detail jangka waktu masa

\footnotetext{
${ }^{26}$ Arief Ikhsanudin, BNPB Bangun Huntara untuk Korban Tsunami di Lampung Selatan, https://news.detik.com/ dan
} https://bnpb.go.id/, 
transisi dan hal-hal yang berkaitan dengan kegiatan-kegiatan yang dilakukan pada masa transisi menuju pemulihan.

\section{Daftar Pustaka}

A. Buku

Agustinus W. Dewantara, Diskursus Filsafat Pancasila Dewasa ini, Penerbit PT Kanisius, Yogyakarta, 2017.

Amhar, Fahmi dan Darmawan, Mulyanto, A Study on Multihazard Maps, Panduan Pengenalan Karakteristik Bencana dan Upaya Mitigasinya di Indonesia, Badan Koordinasi Nasional Penanggulangan Bencana dan Penanganan Pengungsi, Jakarta, 2007.

Carter. Nick, Disaster management: A Disaster Manager's Handbook, ADB, Manila, 1991.

Eny Supartini, dkk, Buku Pedoman Latihan Kesiapsiagaan Bencana, BNPB, 2017.

Hadi Purnomo dan Ronny Sugiantoro, Manajemen Bencana, Media Pressindo, Yogyakarta, 2010.

Imelda Abarquez and Zubair Murshed, field practitioners' handbook, 2004, Thailand.

Khambali, Manajemen Penanggulangan Bencana, CV. Andi Offset, Yogyakarta, 2017.

Ir. Soekarno, Filsafat Pancasila menurut Bung Karno, Media Pressindo, Yogyakarta, 2016.

Salim HS dan Erlies Septiana Nurbani, Penerapan Teori Hukum Pada Penelitian Tesis dan Disertasi, PT RajaGrafindo Persada, Jakarta, 2016.

Winarno, Paradigma Baru Pendidikan Pancasila, Penerbit Bumi Aksara, Jakarta, 2016.

Kaelan, M.S., Filsafat Pancasila, Penerbit "Paradigma", Yogyakarta, 2009.

Fais Yonas Bo'a, Pancasila Dalam Sistem Hukum, Pustaka Pelajar, Yogyakarta, 2017

Pusat Studi Pancasila Universitas Katolik Parahyangan, Pancasila Kekuatan Pembebas, Penerbit PT Kanisius, Yogyakarta, 2012.

B. Jurnal

Ani Rosiyati, Sakai Sambaian: Sistem Gotong Royong di Lampung Timur, Jurnal Patanjala volume 4 No. 1, Maret 2012.

Agus Lanini, Sutarman Yodo, Ikshan Syafiuddin, The Protection of Refugees Rights of Natural Disasters in Central Sulawesi Indonesia, Advances in Social Science, Education and Humanities Research, volume 358, ICGLOW 2019.

Alexius Sunaryo, Mitigasi Bencana Sosial Politik Sebagai Kebijakan Publik Berbasis Demokrasi Pancasila, Mimbar Administrasi Fakultas Ilmu Sosial Dan Ilmu Politik Universitas 17 Agustus 1945 Semarang, Volume 15 No. 29 ISSN 0854-3542, Edisi Oktober 2019.

Deny Hidayat, Kesiapsiagaan Masyarakat: Paradigma Baru Pengelolaan Bencana Alam Di Indonesia, Jurnal Kependudukan Indonesia, Volume III, No. I, 2008.

Eko A Meinarno Sri Fatmawati Mashoedi, Pembuktian Kekuatan Hubungan Antara Nilai-Nilai Pancasila Dengan Kewarganegaraan, Jurnal Ilmiah Pendidikan Pancasila dan Kewarganegaraan, Th. 1, Nomor 1, Juni 2016.

Hilda Maulida, The Implementation of Disaster Management and Legal Protection for Disaster Relief Volunteers (Case of Central Java Province, Indonesia). Journal of Law and Legal Reform, 1(3), 415-424. ISSN (Print) 2715-0941, ISSN (Online) 2715-0968.

HS Tisnanta, Oki Hajiansyah Wahab, Dharma Setyawan, Modal Sosial Dan Komunitas Agama Sebagai Pendukung Instrumen Hukum Dalam Pengelolaan Sampah Di Kota Metro, Jurnal Pemikiran Islam, Volume 19, No. 2, 22 Oktober 2014.

Maulana Irfan, Metamorfosis Gotong Royong Dalam Pandangan Konstruksi Sosial, Prosiding Ks: Riset \& Pkm Volume: 4 Nomor: 1 Hal: 1 - 140 ISSN: 2442-4480, 2016

R.A. Tachya Muhamad, Bintarsih Sekarningrum, Yusar, Modal Sosial Dalam Penanggulangan Bencana Banjir (Kasus di Kabupaten Bandung, Jawa Barat), Jurnal Pemikiran dan Penelitian Sosiologi, Departemen of Sociology, Faculty of Social and Political Science, Universitas Padjadjaran, Bandung.

Rusydi Syahra, Modal Sosial: Konsep dan Aplikasi, Jurnal Masyarakat dan Budaya, Volume 5 No. 1 Tahun 2003. 
Shanti Dwi Kartika, Politik Hukum Penganggulangan Bencana, Kajian Vol. 20 No. 4 Desember 2015.

Sutan Syahrir Zabda, Aktualisasi Nilai-nilai Pancasila sebagai Dasar Falsafah Negara dan Implementasinya Dalam Pembangunan Karater Bangsa, Jurnal Pendidikan Ilmu Sosial, Vol 26, No.2, Desember 2016, ISSN:1412-3835

C. Undang-undang

Undang-Undang Nomor 24 Tahun 2007 tentang Penanggulangan Bencana.

Peraturan Presiden Nomor 1 Tahun 2019 tentang Badan Nasional Penanggulangan Bencana.

Peraturan Daerah Kabupaten Lampung Selatan Nomor 11 Tahun 2014 tentang Mitigasi Regional Bencana Geologi di Wilayah Kabupaten Lampung Selatan.

Peraturan Bupati Lampung Selatan Nomor 05 Tahun 2011 tentang Penanggulangan Bencana.

Peraturan Bupati Lampung Selatan Nomor 16 Tahun 2011 tentang Prosedur Tetap Penyelenggaraan Penanggulangan Bencana Daerah Kabupaten Lampung Selatan.

Keputusan Bupati Lampung Selatan Nomor: B/ 400/VI.02/HK/2018 tentang Penetapan Status Tanggap Darurat Penanganan Bencana Tsunami di Kabupaten Lampung Selatan.

Keputusan Bupati Lampung Selatan Nomor: B/405/VI.02/HK/2018 tentang Penetapan Perpanjangan Status Tanggap Darurat Penanganan Bencana Tsunami di Kabupaten Lampung Selatan.

Keputusan Bupati Lampung Selatan Nomor: B/30/VI.02/HK/2019 tentang Penetapan Perpanjangan Kedua Status Tanggap Darurat Penanganan Bencana Tsunami di Kabupaten Lampung Selatan.

Keputusan Bupati Lampung Selatan Nomor: B/125/VI.02/HK/2019 tentang Penetapan Status Masa Transisi Darurat Menuju Pemulihan Pasa Bencana Tsunami di Kabupaten Lampung Selatan.

Keputusan Bupati Lampung Selatan Nomor: B/334/VI.02/HK/2019 tentang Penetapan Perpanjangan Status Masa Transisi Darurat Menuju Pemulihan Pasa Bencana Tsunami di Kabupaten Lampung Selatan.

Keputusan Bupati Lampung Selatan Nomor: B/381/VI.02/HK/2019 tentang Penetapan Perpanjangan Kedua Status Masa Transisi Darurat. 
